\title{
Manajemen Produksi Pergelaran: Peranan Leadership dalam Komunitas Seni Pertunjukan
}

\author{
Heny Purnomo ${ }^{\mathrm{a}, 1}$, Lilik Subari b, 2, \\ ab Sekolah Tinggi Kesenian Wilwatikta, Jalan Klampis Anom II, Surabaya, Indonesia, 60117 \\ ${ }^{1}$ henimensystem@gmail.com*; 2liliksubari1965@gmail.com
}

\section{INFO ARTIKEL}

Sejarah Artikel:

Diterima: 22-08-2019

Direvisi: 18-11-2019

Disetujui: 18-11-2019

\section{Kata Kunci:}

kepemimpinan

manajemen produksi

pergelaran

seni populer

\begin{abstract}
ABSTRAK
Seni populer selalu menghadirkan ruang sempit terhadap bentuk pertunjukan yang diselenggarakan secara langsung (live). Perkembangan budaya popular kedalam kehidupan seni pertunjukan telah me-munculkan transformasi nilai, ketika lembaga pemerintahan kurang dapat bersinergi dengan komunitas kesenian, maka terjadi berbagai benturan dalam proses berkesenian. Nilai estetik yang hadir melalui proses artistik, kini hanya dijadikan alat mendatangkan nilai ekonomi semata, sehingga "keindahan" sering dimaknai sebagai sesuatuhal yang harus menghasilkan keuntungan secara komersial. Sebaliknya perkembangan seni populer yang ditandai pesatnya media elektronik telah membawa pengaruh terhadap aktivitas produksi pergelaran. Pementasan kesenian tradisi yang diselenggarakan secara langsung sekarang semakin susah dijumpai, dan sering pula menghadapi persaingan dengan kesenian yang telah dikomodifikasikan melalui media televisi. Tumbuh-kembang media televisi bahkan telah memicu pertumbuhan industri hiburan yang berorientasi komoditas dan keuntungan finansial. Tayangan hiburan di berbagai layar media televisi juga dapat memalingkan penonton dari pementasan yang diselenggarakan secara live. Perkembangan seni popular yang didukung teknologi dan kecepatan informasi telah membawa pengaruh transformasi dengan hadirnya industri hiburan, hal tersebut menjadi fenomena yang berdampak terhadap keberadaan pertunjukan maupun perilaku penontonnya. Penelitian bertujuan mendeskripsikan faktor pendukung produksi pergelaran, menjelaskan pengelolaan dan peranan leadership dalam komunitas kesenian. Untuk menganalisa data digunakan teori relevan melalui analogi Goffman, dan manajemen ditunjang konsep kepemimpinan, sehingga hasil penelitian dapat digunakan menjawab fenomena yang terjadi. Penelitian yang menggunakan metode kualitatif dengan pendekatan peranan leadership ini, lebih menitikberatkan teknik pengumpulan data melalui observasi, wawancara, studi pustaka maupun dokumentasi. Penelusuran faktor pendukung dan produksi pergelaran menghasilkan asumsi tentang manajemen serta peranan kepemimpinan dalam keberadaan komunitas seni pertunjukan.
\end{abstract}

\section{ABSTRACT}

Keywords:

leadership

performance

management production popular arts
Popular art always presents a narrow space for live performances. The development of popular culture into the life of the performing arts has bring out to a transformation of values, when government institutions are less able to synergize with the arts community, there are various clashes in the arts process. The aesthetic value that comes through the artistic process, is now only used as a tool to bring economic value alone, so that "beauty" is often interpreted as something that must generate commercial profits. On the other hand, the development of popular art, marked by the rapid growth of electronic media, has had an influence on performance production activities. Performing traditional art which is held directly now is increasingly difficult to find, and often also faces competition with art that has been commodified through television media. The growth of 
television media has even triggered the growth of the commodity-oriented entertainment industry and financial gain. Entertainment shows on various television media screens can also turn the audience away from live performances. The development of popular arts supported by technology and the speed of information has brought the effect of transformation with the presence of the entertainment industry, it has become a phenomenon that has an impact on the existence of the performance and behavior of the audience. The research aims to describe the supporting factors of performance production, explain the management and role of leadership in the arts community. To analyze the data the relevant theory is used through Goffman's analogy, and management is supported by the concept of leadership, so that the results of research can be used to answer the phenomena that occur. Research that uses qualitative methods with this leadership role approach, emphasizes data collection techniques through observation, interviews, literature studies and documentation. Searching for supporting factors and performance production results in assumptions about management and the role of leadership in the existence of the performing arts community.

(C) Cultural Institute, University of Muhammadiyah Malang, Indonesia

\section{PENDAHULUAN}

Keberadaan "pergelaran" berkaitan erat dengan kehidupan seni pertunjukan dan komunitas kesenian yang melibatkan kerja komunal. Perkembangan dan kelangsungan hidup komunitas kesenian sangat bergantung pada kondisi lingkungan masyarakat sebagai pendukung utamanya, sehingga setiap perubahan dalam lingkungan masyarakat membawa pengaruh pula terhadap keberadaan komunitas. Ketika perubahan menjadi konsekuensi suatu "era", maka seharusnya perubahan tersebut dapat dijadikan sebuah kebermanfaatan yang dihasilkan umat manusia dalam masyarakat. Namun perubahan yang terjadi justru sering tidak-dapat bersinergi dengan kehidupan seni pertunjukan maupun komunitas kesenian, sehingga berbagai pergelaran sekarang telah mengalami perubahan bentuk ketika harus memasuki dan bersentuhan terhadap seni popular.

Perkembangan seni populer yang ditandai pesatnya pertumbuhan media televisi berpengaruh terhadap aktivitas produksi pergelaran dan penontonnya. Pementasan yang awal-mulanya diselenggarakan diatas panggung hiburan secara langsung (live) berubah bentuknya ketika ditayangkan dalam media televisi, interaksi yang dibangun antara karya dengan penonton menjadi semu. Sehingga perubahan bentuk pertunjukan sering mengakibatkan penonton dijadikan konsumer atau audien pasif yang komunikasinya direkayasa didepan layarkaca media televisi sebagai ruang panggung dua demensi (2D). Penonton pergelaran sekarang dapat disetting melalui suasana orang tepuk-tangan, tertawa, dan sedih, artinya media televisi memiliki kemampuan menghasilkan serta mengendalikan perilaku penonton dalam perubahan bentuk pergelaran. Munculnya stasiun dan acara televisi yang beragam membuat kesenian tradisi sulit bersaing, disisi lain tidak banyak seniman tradisional yang mampu beradaptasi dengan industri televisi.

Tayangan hiburan di layar televisi banyak berubah menjadi industri seni popular yang memunculkan berbagai persoalan terkait kesenian berbasis kerakyatan. Tayangan acara hampir tidak pernah menyisakan waktu kosong sedikitpun, sebaliknya kemasan pertunjukan yang dilaksanakan dipanggung secara live dianggap ketinggalan jaman, apalagi hiburan juga tidak memberikan keuntungan "pasar". Pendukung kesenian tradisi secara perlahan mulai merosot, sebut saja era dimana komunitas seperti Aneka Ria Srimulat, 
Siswo Budoyo dan sebagainya yang pernah mengalami masa keemasannya, namun kini komunitas hiburan tersebut hanya menjadi bagian dari perjalanan panjang menuju revolusi industri " 4.0 " sebagai era digital yang didukung kecepatan informasi.

Lahirnya media massa dan semakin meningkatnya komersialisasi budaya serta hiburan menimbulkan berbagai permasalahan maupun kepentingan, sekaligus perdebatan yang masih ada sampai sekarang (Strinati, 2003). Perkembangan industri yang kini berorientasi pada komoditas dapat mengakibat transformasi perilaku audiens terhadap berbagai pertunjukan tradisi berbasis kerakyatan (khususnya). Hal tersebut memaksa berbagai komunitas seni pertunjukan ataupun hiburan yang dapat didukung oleh adanya pemilik modal untuk terlibat dan ambil bagian di dalam menghadapi persaingan pasar. Sehingga keberadaan kesenian tradisi pada saat ini dihadapkan pada berbagai tantangan, baik tekanan dari luar maupun ketidakberdayaan dari dalam. Tekanan dari luar terutama datang dari kesenian populer, dan tekanan dari dalam yang berkaitan dengan lemahnya Sumber Daya Manusia (SDM). Kesenian populer tersebut telah didukung oleh berbagai teknologi, sehingga akan lebih mudah dan leluasa untuk mempengaruhi masyarakat (Sudikan, 1997). Pada saat sekarang seni populer (budaya populer) memiliki pengaruh yang sangat kuat terhadap masa depan dan keberadaan seni pertunjukan. Padahal seni pertunjukan dahulu memiliki dayamagnit luarbiasa yang dapat menyedot para penonton, sehingga banyak komunitas kesenian tradisi yang telah mengalami masa kejayaannya. Hal tersebut salahsatunya dapat dilihat lewat persoalan kawasan Taman Hiburan Rakyat Surabaya yang dikenal dengan "Kompleks THR", sebuah wadah hiburan yang didirikan untuk menampung komunitas seni pertunjukan. Kompleks THR menjadi satusatunya pusat kesenian tradisi berbasis kerakyatan, dan merupakan infrastruktur yang dapat dijadikan ruang serta pilar utama bagi pengembangan seni pertunjukan di
Surabaya. Namun dalam kenyataannya, sekarang telah tergerus oleh adanya berbagai kebutuhan dan kepentingan yang tidak berpihak terhadap kehidupan seni pertunjukan. Taman Hiburan Rakyat (THR) sebagai ajang dari berbagai kelompok kesenian rakyat menjadi sepi, bahkan kini telah beralih fungsi, sehingga para senimannya untuk sekedar pentaspun susah bernafas, dan pada akhirnya terus menyingkir dikarenakan tidakbisa bertahan hidup (Dirdjosuseno, 2014). Kompleks THR telah mengalami stagnasi dan tidak ramai lagi oleh datangnya pengunjung, bahkan kegiatan berkaryanyapun kini telah mati dengan adanya kebijakan pengelolanya. Apalagi diperburuk pula dengan perilaku warga yang bertindak sebagai penonton manja seakan tidakperduli dan gampang menyerah dengan ketidak-berdayaan terhadap segala kondisi ataupun situasi yang terjadi.

Kondisi kompleks THR akhirnya berujung memudar dan berhentinya nobong berbagai komunitas kesenian, seperti: Ludruk Irama Budaya, Aneka Ria Srimulat, komunitas kesenian ketoprak dan komunitas wayang orang. Kesenian berbasis rakyat di Surabaya menjadi kurang dikenal dan mudah dilupakan, bahkan saat sekarang untuk menyebut namanya saja sudah mulai terdengar asing oleh masyarakatnya sendiri. Permasalahan tersebut menjadi keprihatinan, mengingat kompleks THR adalah kantong yang digunakan komunitas kesenian sebagai sarana mengembangkan aktivas tontonan, tatanan, dan tuntunan bagi masyarakat. Kondisi sosial masyarakat Surabaya sebagai salahsatu kota metropolis dapat berpengaruh pada perilaku penonton, dan secara tidak langsung akan berdampak pula terhadap setiap pertunjukan yang diselenggarakan (Purnomo,2015). Hal ini merupakan tantangan berat komunitas kesenian yang hidup dan berkembang ditengah masyarakat, sehingga kehadiran manajemen sebagai sistem pengelolaan kini menjadi tumpuan utama untuk mempertahankan kelangsungan hidup. Manajemen didukung model kepemimpinan membawa peranan sangat besar terhadap aktivitas produksi pergelaran 
sekaligus penonton pertunjukan. Berbagai komunitas kesenian berbasis kerakyatan kini menghadapi persaingan dengan industri hiburan berbasis seni populer. Fakta tersebut merupakan fenomena menarik untuk dikaji dengan pertimbangan bahwa: penelitian melalui manajemen produksi pergelaran hingga kini masih jarang dilakukan secara mendalam, khususnya berkaitan kepemimpinan dalam komunitas seni pertunjukan. Untuk menjalankan manajemen dibutuhkan peranan sosok pemimpin dengan model kepemimpinan sebagai pengayom komunitas kesenian maupun didalam memproduksi pertunjukan. Penelitian dilakukan dengan cara menelusuri dan mencermati setiap kegiatan komunitas ludruk Irama Budaya Surabaya sebagai bentuk manajemen atau pengelolaan dengan alasan maupun pertimbangan berikut.

Pertama, adanya korelasi perkembangan media televisi yang pesat dengan merosotnya produksi pergelaran yang berdampak terhadap kehidupan komunitas kesenian, namun ludruk Irama Budaya masih sanggup bertahan hidup bahkan memiliki semangat menyelenggarakan pertunjukan yang kini kurang diminati penonton. Kedua, pertunjukan berbasis kerakyatan terus menghadapi persaingan dengan industri hiburan berbasis seni popular, sehingga berpengaruh terhadap keberadaannya. Ketiga, penelitian tentang kesenian tradisi berbasis kerakyatan yang difokuskan melalui manajemen produksi pergelaran masih jarang dilakukan secara mendalam, khususnya terkait peranan kepemimpinan dalam komunitas seni pertunjukan.

Manajemen menjadi tumpuan utama untuk mendukung keberadaan pertunjukan ludruk Irama Budaya Surabaya, sehingga permasalahan dapat dirumuskan 1) apakah yang menjadi dayadukung komunitas ludruk Irama Budaya Surabaya? 2) bagaimana manajemen produksi pergelaran ludruk Irama Budaya Surabaya? dan 3) bagaimana peranan kepemimpinan dalam komunitas ludruk Irama Budaya Surabaya?

\section{METODE}

Keberadaan pertunjukan ludruk Irama Budaya merupakan fenomena sosial yang terjadi dalam kehidupan komunitas seni pertunjukan. Pertunjukan adalah kegiatan komunikasi sebagai muara kekaryaan komunitas kesenian, sehingga untuk memahami berbagai fenomena digunakan pendekatan manajemen produksi pergelaran sebagai sistem pengelolaan dalam pementasan. Untuk mendalami manajemen dibalik kegiatan menghasilkan kekaryaan tersebut, penelitian difokuskan melalui peranan kepemimpinan dalam komunitas seni pertunjukan.

Dalam memperoleh data lapangan, penelitian menggunakan: 1) observasi untuk mengamati beberapa partisipan maupun memahami fenomena yang berhubungan secara langsung maupun tidak langsung terhadap pertunjukan, serta memiliki hubungan dengan objek maupun subjek penelitian; 2) wawancara terhadap informan untuk me-ngumpulkan data yang merujuk fokus atau rumusan penelitian; 3) Studi kepustakaan dan dokomen untuk mendapatkan data-data referensi yang berhubungan kehidupan kelompok ludruk Irama Budaya ketika awal-mula didirikan.

Untuk temuan hasil penelitian tentang keberadaan komunitas ludruk Irama Budaya, kegiatan yang dilakukan adalah mengklasifikasikan hingga memberi makna terhadap hasil pengamatan, wawancara, pencatatan, dan perekaman yang telah diperoleh melalui pengumpulan data dari berbagai informasi mengenai fenomenafenomena yang terjadi sebagai objek penelitian. Menurut Emzir (2012), bahwa tugas analisis menafsirkan dan membuat makna materi-materi yang telah dikumpulkan dapat muncul sebagai tugas monumental ketika seseorang untuk pertama kalinya terlibat dalam proyek penelitian

Menurut Lincoln dan Guba, sedikitnya terdapat empat standar atau criteria utama untuk menjamin keabsahan data hasil penelitian kualitatif, yaitu: a) standar kredibilitas, b) standar transferabilitas, c) standar dependabilitas, dan d) standar 
konfirmabilitas (Bungin,2012). Dalam penelitian ini, keabsahan data difokuskan pada standar kredibilitas, hal ini agar data hasil penelitian kualitatif memiliki tingkat kepercayaan tinggi sesuai fakta dilapangan, yaitu informasi yang digali lewat subjek atau partisipan yang diteliti.

Penelitian tentang keberadaan komunitas ludruk Irama Budaya, validasi data dilakukan melalui triangulasi untuk mengutamakan efektivitas proses dan hasil yang diinginkan.Triangulasi dilakukan dengan menguji proses dan hasil metode yang diguna-kan sudah berjalan baik. Proses triangulasi dilakukan terus menerus sepanjang proses mengumpulkan data maupun analisis data, sampai peneliti merasa yakin tidak ada lagi perbedaanperbedaan, dan tidak ada yang perlu dikonfirmasikan kepada para informan yang didapatkan dari dalam maupun luar komunitas ludruk Irama Budaya Surabaya.

\section{HASIL DAN PEMBAHASAN Memahami Budaya Populer dan Seni Populer}

Budaya Populer adalah budaya massa yang dalam perjalanannya terbentuk lewat perkembangan masyarakat massa. Massa disini hanya dapat dilahirkan melalui adanya proses industrialisasi maupun urbanisasi, dan dampak yang ditimbulkan menjadi kunci utama. Kata "massa" diartikan sebagai masyarakat awam, populasi manusia, publik, kumpulan orang-orang sebagai khalayak, dan kumpulan warga sebagai penduduk kota.

a). Masyarakat Massa: masyarakat yang keberadaanya akibat pengaruh proses industri-alisasi dan urbanisasi sebagai gerakan yang hadir dalam kehidupan kota, perubahan terjadi terkait sesuatu yang dihasilkan industri maupun akibat semakin padatnya kota-kota besar dari pesatnya pertumbuhan penduduk. Menurut Wirth: kehidupan kota didasarkan adanya sejumlah besar orang-orang yang hidup berdekatan tanpa mereka mengenal satu sama lainnya, sehingga telah mengharuskan mereka untuk menjalankan transaksi instrumental dan mengabaikan pertemuan diantara mereka (Barker, 2011). Kehadiran dari masyarakat massa, sebagai suatu langkah untuk dapat menanamkan sebuah kekuasaan terhadap berbagai lembaga, industri-industri dagang, media massa, dan merupakan salahsatu cara atau upaya menunjukkan adanya potensi yang terbuka untuk propaganda massa, dan potensi kaum elite dalam memanfaatkan media massa untuk membujuk, mempersuasi, serta memanipulasi, maupun mengeksploitasi orang banyak secara lebih sistematis dan merata dibandingkan dari sebelumnya.

b). Budaya Massa: pengaruh hubungan antar manusia dalam masyarakat massa adalah hubungan yang semu, hubungan yang tidak didasarkan atas adanya sifat komunal serta terintegrasi. Individu-individu yang ada di dalamnya, jelas-jelas tidak memiliki adanya ikatan moral yang didasarkan nilai-nilai kehidupan, dan tidak adanya rasa kebersamaan antar sesama maupun komunitasnya.Ketika tatanan moral telah mengalami kemunduran dan nilai-nilai kehidupan secara layak juga sulit untuk didapatkan serta dipenuhi di dalam masyarakat massa, maka warga atau penduduk itu nantinya akan mencari dan berpaling kepada pengganti moralitas, serta nilai-nilai yang didasarkan atas kehidupan. Akhirnya kehadiran budaya massa memiliki peranan sebagai pengganti krisis moralitas dan nilai-nilai kehidupan di dalam masyarakat massa. Budaya massa menjadi ancaman dikarenakan sifat homogennya, dan kapasitasnya dalam menurunkan atau merendahkan segala kebudayaan, serta menciptakan kembali dengan pencitraannya sendiri, sehingga bisa didefinisikan bahwa: Budaya massa adalah kekuatan revolusioner dinamis, yang menghancurkan batasan kelas kuno, tradisi, selera, dan mengaburkan segala macam perbedaan. Budaya massa akan membaurkan dan mencampur-adukkan segala sesuatu, menghasilkan apa yang disebut budaya homogen. Dengan demikian budaya massa akan menghancurkan segala nilai, karena penilaian dapat 
mengimplikasikan adanya sebuah diskriminasi/pembedaan. Budaya massa teramat sangat demokratis: ia secara mutlak akan menolak untuk mendiskriminasikan atas, ataupun antara, serta apa pun, maupun siapa pun (Strinati, 2003).

Ketika massa atau populasi mulai dipandang sebagai penentu utama negara, dan putusan-putusan yang dihasilkan merupakan akibat dari perluasan hak-hak politik kewarganegaraan, maka ekspresi lebih jauh dari kecenderungan dalam bidang budaya, yang dipadukan dengan berbagai dampak dari pendidikan dasar secara universal, ditengarai akan menghasilkan determinasi populer budaya masyarakat massa. Teori masyarakat massa dan budaya massa biasanya didasarkan pada suatu pemilahan yang jelas antara masa lalu dan masa kini. Pemilahan tersebut biasanya merujuk terhadap proses perubahan sosial yang dipandang sebagai suatu transisi dari masa lalu yang lebih baik dan lebih disukai menuju masa kini dan masa depan yang memburuk dan tidak menarik (Strinati, 2003).

c). Budaya populer: sebelum terbentuk masyarakat massa,terlebih dahulu telah terbentuk masyarakat komunal yang bersikap menerima dan mematuhi terhadap seperangkat nilai untuk disepakati bersama. Mereka menerima dan mengakui adanya perbedaan dalam komunitas yang berintegrasi. Dalam masyarakat demikian terdapat tempat tumbuh dan berkembang bagi "kesenian" dan budaya elit, tersedia ruang bagi "budaya rakyat" yang benarbenar populer serta terlahir dari masyarakat bawah. Budaya rakyat tidak pernah memberi ilham kesenian,tetapi kekhasannya bisa diterima dan dihargai, industrialisasi dan urbanisasi akhirnya merubah situasi tersebut. Komunitas dan moralitas terceraiberai, individu-individu menjadi semakin terisolasi, teralienasi,dan anomik,satusatunya hubungan yang terjadi merupakan hubungan yang bersifat finansial dan kontraktual.
Budaya populer mengacu pengertian budaya massa: a) budaya berbasis massa yang muncul sebagai budaya massa; b) budaya diproduksi secara massal untuk tujuan komersial sehingga menghasilkan keuntungan finansial; c) budaya yang perkembanganya terkait munculnya peranan media televisi sebagai media massa; d) budaya yang dikendalikan kekuasaan massa (penonton). Istilah seni populer merujuk pengertian budaya populer yang diartikan: a) seni yang berkembang karena memiliki dan adanya dukungan massa, b) bentuk seni diproduksi secara massal (luas) untuk mendatangkan massa (penonton), dengan tujuan menghasilkan nilai komersial; c) seni yang perkembangannya terkait peranan media televisi sebagai industri yang memproduksi hiburan; dan d) seni yang perkembangannya dikendalikan kekuasaan atau selera penonton. Konsep seni populer didasarkan pada perkembangan budaya populer dengan semakin tumbuhkembangnya media televisi, mereka lebih memperkuat bentuk seni populer hadir dan berkembang melalui berbagai tayangan seni hiburan dilayar media televisi yang dibagi dua bagian:

(1) Produksi Seni Populer, menurut Barber secara spesifik konsep seni populer mencakup seni yang muncul dari masyarakat kelas urban. Seni populer diproduksi perorangan, yaitu para penghibur profesional, tetapi hanya akan mencapai kesuksesan jika seni ini dapat mengartikulasikan nilai-nilai dan sentimen kolektif (populer), yang disodorkan kembali serta dikonfirmasikan oleh senimannya kepada audiens atau massa (Smiers, 2009). Pada awalnya seni populer tersebut diproduksi untuk dapat mendatangkan selera massa yang tidak memandang adanya genre penonton secara khusus. Maka seni popular disebut juga sebagai seni populis (penggalang massa), adalah karya seni dengan intensitas produksi secara massal sehingga dinikmati juga secara luas, bukan semata-mata hanya pada kelompok elit. Oleh karena itu, sama seperti novel populer, 
seni populer belum tentu bernilai rendah (Ratna, 2013). Seni populer diproduksi berkaitan dengan selera penonton (massa) yang memang membutuh- kan kehadiran sebuah karya seni, artinya karya seni tersebut hadir karena memang "disukai orang banyak". Bahwa jenis seni ini disukai orang banyak dapat dilihat dari banyak dan seringnya produk seni yang bersangkutan dihasilkan. Hal ini dapat berarti bahwa produk seni yang banyak itu terjadi secara bertahap sebagai tanggapan atas kebutuhan yang sungguh - sungguh berdasarkan "permintaan pasar" (Sedyawati, 2008).

\section{(2) Industri Seni Populer,masyarakat} modern yang menguasai kehidupan menempatkan dan menganggap industri serta perdagangan sebagai tiang penyangga kesejahteraan hidup manusia. Sehingga kesenian khususnya seni rakyat, menjadi ranah paling effektif diciptakan dan direkayasa sebagai komoditas oleh mesin budaya populer, yaitu media massa (televisi). Perkembangan stasiun televisi yang pesat memicu persaingan tayangan hiburan menjadi komoditas,sehingga membuka peluang tumbuhnya industri seni populer. Menurut Fiske (2011) media televisi sebagai contoh paradigma industri budaya, bisa menelusuri produksi dan distribusi komoditas-komoditas dalam dua perekonomian yang sejajar serta semi otonom yang disebut "perekonomian finansial" (mengedarkan kemakmuran dalam dua subsistem) dan "perekonomian budaya" (mengedarkan makna dan kepuasan). Studio produksi yang menghasilkan komoditas, program, dan menjual kepada distributor atau jaringan televisi untuk mendapat keuntungan. Ini bentuk pertukaran finansial yang berlaku bagi semua komoditas, namun program televisi atau komoditas budaya tidak sama dengan komoditas material.Fungsi ekonomi program televisi tersebut belum lengkap ketika dijual, karena momen konsumsinya telah berubah menjadi produsen, dan yang diproduksi adalah audiens (penonton) yang kemudian dijual kepada pengiklan. Produk terpenting industri budaya (hiburan) adalah audiens terkomodifikasi yang nanti dijual kepada para pengiklan.

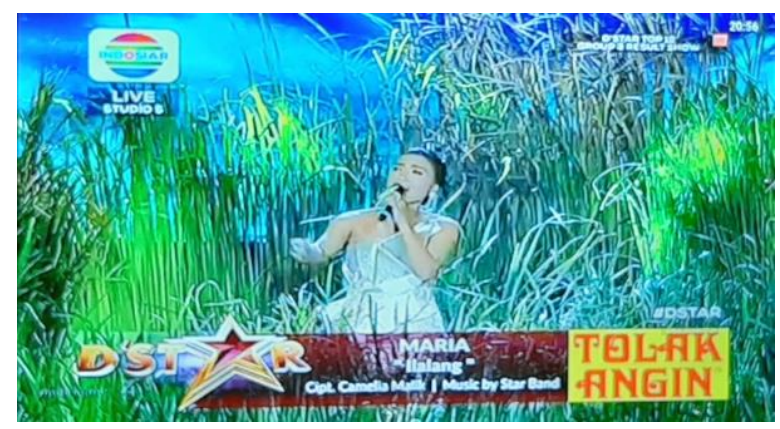

Gambar 1: Bintang segala Bintang Dangdut (D'STAR) dalam Industri Seni Populer, model tayangan yang dikomodifikasikan melalui media televisi (Dok.Henimen, 2019).

Tumbuh dan berkembangnya jumlah stasiun televisi swasta yang semakin pesat, memicu persaingan dalam menayangkan program hiburan menjadi sebuah komoditas, dan membuka peluang tumbuhnya "industri seni populer". Perkembangan seni populer dalam bentuk seni pertunjukan, sekarang menjadi komoditas untuk menghasilkan uang di dalam industri seni populer. Namun sangat mungkin produk itu merupakan tindakan perdagangan yang strategis dengan merekayasa berbagai kebutuhan dalam masyarakat lewat usaha promosi. Karena itu tidak heran kalau MTV begitu cerdas membidik penonton dikalangan anak muda. Dengan strategi penayangan program hiburan yang menarik, dan tampaknya MTV berhasil dalam upaya mengembangkan dan meng-eksploitasi budaya kawula muda internasional.Pada saat yang sama MTV juga berhasil menawarkan nilai konsumerisme, konsep diri yang dikomoditaskan, dan gaya hidup yang dikemas dengan kriteria dan standart hiburan global, tetapi tetap memperhatikan nilai kelokalan (Ibrahim, 2011).

Signifikansi budaya populer di zaman modern, bisa dipetakan berdasarkan budaya populer yang identifikasikan melalui gagasan budaya massa. Pengertian budaya populer di Indonesia dapat dimaknai dengan pemahaman menurut permasalahan yang sekarang sedang berkembang pesat. Budaya populer yang dianggap penting di dalam 
situasi mutakhir Indonesia tidak sematamata terbatas pada cara pandang dan perilaku elit politik nasionalnya. Namun tidak ada satupun pranata sosial di Indonesia yang sanggup menyita perhatian masyarakat dalam lingkup yang berhasil atau intensitas setinggi yang telah dicapai media televisi (Heryanto, 2012).

\section{Faktor Pendukung Komunitas Ludruk Irama Budaya}

Irama Budaya adalah komunitas ludruk yang didirikan dikota Surabaya dan masih memiliki keberadaan. Komunitas ludruk ini didukung berbagai faktor yang langsung berhubungan kegiatan diatas panggung:1) penyutradaraan; 2) pemeranan dan 3) artistik. Sedangkan faktor pendukung yang tidak langsung berhubungan dengan kegiatan diatas panggung adalah masalah pengelolaan. Dalam penelitian ini faktor pendukung komunitas difokuskan pada masalah pengelolaan yang meliputi berbagai bidang, seperti berikut.

\section{Basis Manajemen}

Manajemen atau mengelola adalah kegiatan mengatur yang dapat diterapkan dimana saja dan kapan saja. Banyak hal dapat dilakukan dan digarap dengan baik melalui kegiatan manajemen, mulai manajemen komunitas keseniannya, manajemen pertunjukannya, dan manajemen proses kekaryaannya, hingga pada manajemen penataan ruangnya. Manajemen merupakan faktor penting yang sangat menentukan dalam komunitas kesenian dan kegiatan pertunjukan, meskipun basis manajemen tersebut berada di luar kebutuhan artistik, namun manajemen dapat menyatukan adanya berbagai kebutuhan dalam komunitas seni pertunjukan. Menurut Permas dkk (2003), banyak organisasi seni pertunjukan yang sangat bagus dari aspek artistik, namun karena tidak dimanajemeni (dikelola) dengan baik akhirnya dapat bubar.

Manajemen membantu organisasi seni pertunjukan mencapai tujuan secara efektif dan efisien. Ketika komunitas ludruk Irama Budaya masih menyelenggarakan pertunjukan secara keliling (nobong), pengelolaannya dilakukan sangat sederhana lewat manajemen model juragan dengan pendekatan kekeluargaan.Dalam komunitas kesenian tradisi berbasis kerakyatan, manajemen model juragan tidak berbeda jauh dengan model manajemen kesenian tradisi lainnya seperti: ketoprak, ludruk, wayang orang dan sebagainya yang memiliki juragan, sebagaimana orang yang memimpin ataupun mengatur anggota-anggota dalam kelompok tersebut. Karena pada dasarnya, manajemen tersebut adalah cara bagaimana memanfaatkan input untuk menghasilkan karya seni lewat suatu proses perencanaan, pengorganisasian, pengarahan, dan pengendalian, dengan memperhatikan situasi maupun kondisi lingkungannya.

\section{Patron Komunitas}

Untuk menjaga kelangsungan hidup komunitas seni pertunjukan, manajemen perlu disertai "patron" sebagai pendukung di dalam setiap kegiatan pertunjukan. Patron, merupakan lembaga ataupun seorang tokoh, yang dapat "mengayomi" maupun memberikan berbagai dukungan materi dan spiritual terhadap berbagai kegiatan pementasan komunitas ludruk Irama Budaya. Komunitas kesenian tradisi berbasis kerakyatan, sekarang dalam menghadapi berbagai persoalan berkaitan keberadaan komunitas sering mengandalkan patron sebagai pengayom komunitas. Untuk menjadi patron amat dibutuhkan lembaga ataupun sosok yang mempunyai kemampuan menjalankan sistem pengelolaan komunitas ludruk Irama Budaya.

Manajemen itu sangat tergantung dari organisasi pengaturnya sebagai lembaga yang berkuasa, jadi di dalam lembaga tersebut, terdapat orang-orang yang memiliki kekuasaan untuk mengatur apa yang di bawahnya. Sehingga lembaga seharusnya menjadi patron yang dapat melindung komunitas kesenian. Namun sekarang ini birokrasi terkadang kurang tanggap dan respon dengan keadaan, termasuk yang berkaitan dengan lembaga 
ataupun instansi yang tidak mengerti tentang strategi kebudayaan, apalagi mereka tidak memiliki kemampuan mengelola, seperti terjadi dikompleks THR beserta kelompok kesenian didalamnya. Sehingga kemungkinan kecil apabila lembaga semacam UPTD THR Surabaya untuk menjadi patron bagi kelompok ludruk Irama Budaya dalam arti sesungguhnya.

\section{Kemasan Cerita}

Kemasan cerita yang dimaksud tidak sekedar berbicara jalannya cerita sebuah pementasan, namun merupakan bentuk pertunjukan ludruk Irama Budaya sebagai hasil karya seni pertunjukan secara keseluruhan. Jika dipahami lewat waktu dan keadaan,kemasan cerita ludruk Irama Budaya telah memiliki perkembangan ataupun perjalanan tersendiri sebagai karya seni pertunjukan atau hiburan.Kemasan cerita pementasan ludruk Irama Budaya dari dahulu hingga sekarang masih tidak berubah, kecuali ada permintaan tertentu berkaitan dengan tema acara, biasanya berhubungan dengan peringatan hari-hari besar nasional.Untuk menentukan kemasan cerita, harus benar-benar mengerti serta memahami selera penonton. Bentuk kemasan cerita pada ludruk Irama Budaya, sejak dahulu dirancang lewat perjalanan komunitas tersebut.

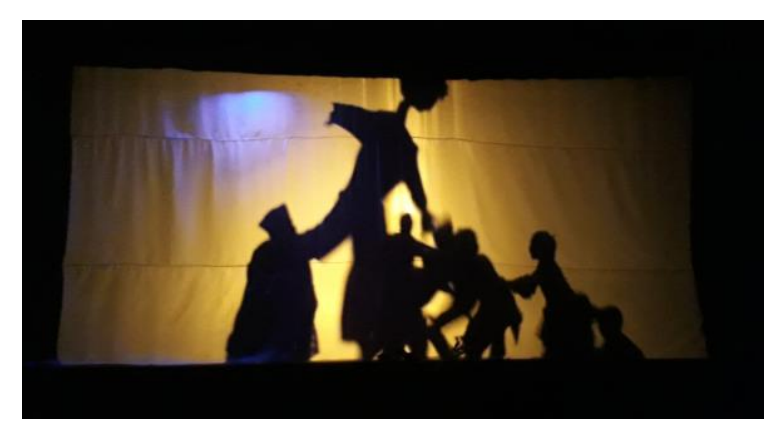

Gambar 2: Jalan cerita yang dikemas melalui tayangan silhouette, menggambarkan orang-orang/penduduk yang diusir orangorangan/penguasa (Dok.Henimen, 2019).

\section{Aktor Pendukung}

Aktor atau seniman pemeranan adalah seniman yang mewujudkan peran lakon kedalam realita seni pertunjukan,sebagai seniman ia tidak bisa lepas dari unsur-unsur kemanusiaan yang umun,juga dari fungsinya sebagai manusiautuh dalam lingkungan serta tatanilai tempat ia hidup dan berkarya. Daya tarik/kharisma pribadi akan tampil dan menjadi sangat penting berkat penampilan dan caranya menyelesaikan masalah-masalah yang dihadapi (Anirun,1998). Setiap cerita yang dilakonkan akan selalu berusaha dilakukan dengan pengkemasan yang menarik.

Aktor pendukung komunitas ludruk Irama Budaya, sekarang ini merupakan kolaborasi antara pemain senior dengan para pemain muda. Persoalan regenerasi pemain memang sangat sulit dan berlaku bagi komunitas seni pertunjukan manapun, apalagi dengan model hiburan seperti ludruk Irama Budaya yang memiliki karakter pemain berdeda-beda.Sekarang ini jarang pemain yang memiliki kemampuan handal dalam bermain seperti yang dilakukan para seniornya. Persoalan pemain pertunjukan ludruk Irama Budaya sangat kompleks, terutama berkaitan Sumber Daya Manusia (SDM) yang kurang berkembang ataupun masalah manajemen yang amburadul. Dahulu karena komunitas ludruk Irama Budaya masih dikelola Mak Sakia, meskipun pertunjukan diselenggarakan secara nobong, namun semua masih dapat terkontrol.

\section{Penonton Pertunjukan}

Penonton dalam pertunjukan adalah orang-orang yang mereka secara sengaja menginginkan untuk mendapatkan rasa kepuasan dari hasil menonton. Mereka pergi menonton dengan maksud yang pertamatama memang untuk memperoleh kepuasan rasa, lalu kebutuhan dan keinginannya juga dapat terpenuhi (Harymawan, 1988). Dengan kata lain, seorang penonton ingin mendapatkan suatu kepuasan batin sebagai oleh-oleh yang menarik untuk dibawa pulang tanpa terbebani hal-hal yang lainnya. Penonton merupakan faktor pendukung sangat menentukan dalam pertunjukan ludruk Irama Budaya dan menjadi tujuan akhir setiap pergelaranya. Persoalan terletak pada perbedaan situasi dan kondisi pementasan ludruk Irama Budaya, penonton 
masa sekarang bukanlah penonton masa kejayaan pertunjukan dahulu. Mereka merupakan penonton yang dibentuk zamannya masing-masing, sehingga memiliki selera dan perilaku berbeda pula. Penonton sekarang merupakan penonton yang diasuh dan dibesarkan kejayaan media televisi dan rentan dipengaruhi kondisi di lingkungannya.

Kejayaan suatu pertunjukan dapat ditentukan oleh kehadiran penonton, ketika penonton sepi meninggalkannya, maka pertunjukanpun menjadi semakin memudar keberadaannya. Berbagai faktor sosial dalam masyarakat saat sekarang menjadikan pertunjukan kesenian tradisi sepi penonton, akhirnya hal tersebut menjadi pemicu persoalan terkait pementasan berikutnya. Pertunjukan ludruk Irama Budaya terus menghadapi persaingan hiburan yangkini mulai berkembang sangat pesat. Penonton maupun pertunjukan menjadi dua hal yang saling berkaitan dan sulit dipisahkan, sehingga merupakan unsur utama untuk mengukur kesuksesan sebuah pertunjukan.

\section{Manajemen Produksi Pergeleran}

Pengertian manajemen selalu dikaitkan fungsi-fungsi yang sekaligus digunakan mendefinisikannya, menurut R.Terry: manajemen adalah proses khas yang terdiri dari tindakan perencanaan, pengorganisasian, penggerakan, dan pengendalian yang dilakukan untuk menentukan serta mencapai sasaran yang telah ditentukan melalui pemanfaatan sumber daya manusia dan sumber-sumber lainnya (Amirullah dan Budiyono, 2004). Seni pertunjukan dan pergelaran dalam proses berkesenian sulit dipisahkan, karena pergelaran adalah implementasi seni pertunjukan untuk ditampilkan kepada penonton. Sebagai bentuk organisasi, seni pertunjukan maupun pergelaran dalam kegiatannya dapat berjalan secara terpisah, bahkan menggunakan proses pengelolaan yang berbeda. Organisasi seni pertunjukan merupakan wadah kegiatan untuk menghasilkan karya seni, ketika kehidupan seni pertunjukan bermuara untuk memproduksi suatu pergelaran, maka kehadiran manajemen sangat dibutuhkan dalam menunjang penyelenggaraanya.

Pergelaran dapat diselenggarakan dalam waktu sesaat atau waktu cukup lama, dapat diselenggarakan orang-orang (pengurus) yang sekaligus penyelenggara organisasi ataupun orang-orang (panitia) yang baru saja dibentuk. Pergelaran dapat menampilkan karya berbentuk tradisi, modern, kontemporer,dan kolaborasi,bahkan pergelaran kolosal sekalipun, namun semua akan menentukan pula sistem manajemen yang dijalankan. Setiap penyelenggaraan pergelaran memiliki persoalan, karakter, maupun keunikan berbeda yang dapat dipengaruhi situasi dan kondisi lingkungan dimana seni pertunjukan tersebut hidup serta berkembang. Pergelaran atau pertunjukan dapat diselenggarakan sebagai hiburan rutin, festival, lomba (kompetisi), lawatan (eksebisi), digunakan untuk mencari keuntungan secara ekonomi, penggalangan dana, yang diselenggarakan secara gratis untuk umum, kalangan terbatas, bahkan pertunjukan untuk undangan tertentu.

Produksi pergelaran merupakan organisasi yang kompleks, dalam pelaksanaannya memiliki dua aspek sekaligus yang harus dijalankan, yaitu aspek ekonomi serta aspek artistik. Produksi pergelaran senantiasa menitik-beratkan pada persoalan menghasilkan pertunjukan yang sukses dan memiliki daya-tarik dengan target kepuasan penonton. Sebagai organisasi seni pertunjukan maupun pergelaran juga merupakan aspek yang menunjang kebutuhan kejiwaan manusia yang pada aktivitasnya senantiasa melibatkan adanya interaksi antara karya, pemain, dan penonton. Kebutuhan kejiwaan, mencakup kebutuhan akan etika, moral, keindahan, kesenian, dan hiburan (Purba, 2005).

Manajemen produksi pergelaran, adalah cara memanfaatkan unsur-unsur dalam organisasi untuk menghasilkan suatu event pertunjukan melalui proses perencanaan, pengorganisasian, penggerakan dan pengawasan, dengan mempertimbangkan situasi serta kondisi lingkungan. Keberadaan 
manajemen produksi pergelaran bisa menunjang dalam penyelenggaraan pertunjukan secara efektif dan efisien sesuai tujuan organisasi. Kegiatan pengelolaan menitikberatkan persoalan untuk menghasilkan pertunjukan yang bermutu dengan target kepuasan penonton. Sehingga untuk memenuhi kebutuhan dan mencapai tujuan tersebut, manajemen sebagai sebuah sistem yang digunakan dalam suatu organisasi akan dijalankan secara maksimal. Menurut Soedarsono (2010) perlu diperhatikan, semua bentuk seni pertunjukan diperlukan biaya untuk meng-hadirkannya diatas panggung pertunjukan, dalam dunia manajemen seni pertunjukan lazim disebut sebagai ongkos produksi (production cost). Ongkos produksi terkait dengan siapa yang menjadi penikmat dari produk pertunjukan, atau siapa yang menjadi sponsor utama dari para seniman pertunjukan dalam menghadirkan karya-karyanya.

\section{Kepemimpinan dalam Komunitas Seni Pertunjukan}

Hubungan

antara komunitas, manajermen, dan kepemimpinan merupakan sesuatu hal yang tidak dapat dipisahkan, saling terikat serta terkait untuk saling melengkapi. Komunitas sebagai wadah, manajemen dan kepemimpinan sebagai alat untuk memenuhi kebutuhan serta mencapai tujuan secara bersama. Komunitas seni pertunjukan dapat bertahan hidup dan berkembang biasanya dikarenakan keuletan dan kepemimpinan yang dijalankan sosok pemimpinnya. Kepemimpinan (leadership) adalah kemampuan yang dimiliki seseorang untuk mempengaruhi orang lain agar bekerjasama sesuai rencana demi tercapainya suatu tujuan. Kepemimpinan adalah hubungan saling mempengaruhi antara pemimpin dan pengikut (bawahan) yang menginginkan adanya perubahan nyata yang mencerminkan tujuan bersama. Menurut Suganda (2002) meskipun pemimpin kenyataannya benar-benar mempengaruhi bawahannya dengan berbagai cara, namun para pemimpin juga dipengaruhi bawahan mereka. Dalam kenyataannya dapat dikatakan bahwa kepemimpinan ada hanya dalam hubungan dengan pengikut. Dalam pengertian demikian, bahwa tidak akan ada seorangpun yang dapat memimpin tanpa pengikut.

Perkembangan seni populer selalu menghadirkan ruang sempit bagi segala bentuk kegiatan komunitas kesenian yang kemasan pertunjukan masih diselenggarakan secara langsung. Industri hiburan yang dikomodifikasikan lewat media televisi, kini banyak memberi perubahan pada kehidupan seni pertunjukan, sehingga untuk mempertahankan kelangsungan hidup komunitas kesenian sangat membutuhkan adanya kepemimpinan. Menurut Daft dan Rost: kepemimpinan merupakan salahsatu fenomena paling mudah diobservasi, tetapi menjadi salahsatu hal yang sulit dipahami, dan kepemimpinan adalah hubungan yang saling mempengaruhi diantara pemimpin dan pengikut (bawahan) yang menginginkan perubahan nyata yang mencerminkan tujuan bersamanya (Safaria, 2004).

Kepemimpinan adalah inti keseluruhan proses kegiatan manajerial dalam produksi pergelaran yang memiliki tugas berat menjalankan manajemen, karena pemimpin adalah orang yang bertanggungjawab secara keseluruhan tentang pekerjaan yang dijalankan. Beberapa persoalan seperti jadwal pertunjukan yang tidak pernah tuntas, merosotnya penonton, bahkan sekarang muncul kasus penutupan pusat kegiatan kesenian tradisi Taman Hiburan Rakyat (THR) Surabaya, menjadi urusan yang mesti dapat diselesaikan oleh pemimpin. Seorang pemimpin harus mempunyai kemampuan dalam memilih dan menentukan keputusan dengan mendasarkan pada kebutuhan dan tujuan organisasi, hal tersebut dikarenakan kegiatan organisasi produksi pergelaran memiliki persoalan yang kompleks, sehingga membutuhkan kemampuan manajerial yang handal.

Kepemimpinan dalam organisasi produksi pergelaran selain memiliki kemampuan manajerial juga dibutuhkan wawasan tentang artistik. Tugas pokok pemimpin organisasi sebenarnya adalah 
melaksanakan fungsi-fungsi manajemen, namun terlaksananya tugas tersebut tidak bisa dicapai hanya oleh pimpinan seorang diri, tetapi dengan menggerak-kan orangorang yang dipimpin, sehingga yang dipimpin tersebut mau bekerja secara efektif dan efisien (Murgiyanto,1985). Berbagai faktor pendukung dalam komunitas kesenian dapat berpengaruh terhadap keberhasilan pergelaran, seperti: basis manajemen, patron pertunjukan, pemain pendukung, dan penonton pertunjukan. Ironisnya ketika memasuki industri hiburan, faktor-faktor pendukung tersebut telah dikomodifikasikan melalui kehadiran media televisi, dan sangat berkaitan dengan persoalan komersial maupun dunia kapitalis. Menurut Ibrahim (2011) betapa eratnya hubungan antara kebangkitan dunia seni populer dengan kapitalisme, sehingga dapat diibaratkan seni populer dan kegiatan dagang adalah seperti air dan ikan. "Ikan" seni populer tidak mungkin hidup di luar "air" dagang. Selera massa harus dilayani, kalau modal mau kembali dan berkembang. Maka ukuran kesuksesan seni populer biasanya terletak pada gemuruhnya tepuk tangan dari publik (penonton). Semakin riuh rendah tepukannya, semakin riuh rendah pula gemerincing uangnya. Seni populer yang baik pada gilirannya adalah seni populer yang banyak mendatangkan uang, bukan pada nilai seninya itu sendiri. Kapitalisme global adalah panggung tempat arena konstruksi kebudayaan yang akan dimainkan, tempat rekayasa selera dikemas, dan tempat impian ditaburkan. Kapitalisme global juga tampil sebagai panggung tempat terjadinya pertarungan sub-kultur dan perburuan identitas yang tanpa akhir dan seakan tanpa pemenang.

Kepemimpinan dalam organisasi produksi pergelaran memiliki peranan sangat besar untuk tercapainya tujuan, dan para pemimpin harus dapat mempengaruhi moral dan kepuasan kerja, keamanan, kualitas kehidupan kerja, dan tingkat prestasi suatu organisasi. Kepemimpinan juga memainkan peranan kritis dalam membantu kelompok, organisasi, atau masyarakat, dikarenakan bagaimanapun kemampuan dan ketrampilan kepemimpinan adalah faktor penting demi perkembangan serta kelangsungan hidup komunitas kesenian. Sehingga untuk mendukung penyelenggaraan sebuah pergelaran, maka aspek ekonomi maupun artistik telah menjadi kebutuhan utama yang diwujudkan melalui kegiatan manajerial. Seorang pimpinan ketika sedang menghadapi persoalan produksi pergelaran, akan bekerja keras dan berusaha secara maksimal menjalankan manajerial serta mencari solusi terhadap berbagai tekanan yang terus menghimpitnya.

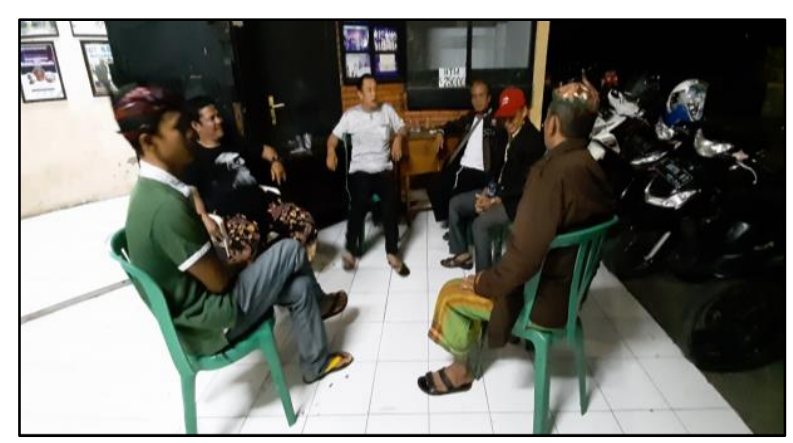

Gambar 3. Kepemimpinan dalam Komunitas Ludruk Irama Budaya. Juragan (patron) harus selalu hadir di tengah komunitas (Sumber: Dok. Henimen 2019)

Berbagai kesenian rakyat sepeninggal "patron"nya seakan-akan juga telah kehilangan pamornya, yang semakin hari juga semakin ditinggalkan oleh masyarakat penikmatnya. Dalam era komunikasi yang semakin canggih saat ini, masyarakat telah dihadapkan pada banyak pilihan untuk mendapatkan hiburan (Sudikan, 1997). Seorang pemimpin pada sebuah komunitas seni pertunjukan itu, belum tentu dapat bertindak sebagai patron seperti Mak Sakia (alm.) didalam komunitasnya. Sebab untuk menjadi patron komunitas ludruk Irama Budaya, selain memiliki kepedulian yang tinggi terhadap kelompok yang dipimpin, haruslah memiliki kemampuan dalam manajemen dan kekuasaan menentukan kebijakan, serta segala hal yang berkaitan dengan kelangsungan hidup komunitas. Sehingga sebagai sosok pimpinan produksi, maka haruslah seseorang yang tangguh dan memiliki kemampuan yang handal dalam kepemimpinannya pada komunitas kesenian. 


\section{KESIMPULAN}

Perkembangan budaya populer selalu memberi ruang yang semakin sempit bagi segala jenis kebudayaan yang tidak dapat menghasilkan uang, dan sesuatu yang tidak dapat diproduksi secara massal bagi massa seperti halnya kesenian serta budaya rakyat. Seni popular awal-mulanya merupakan kesenian berbasis kerakyatan, namun sekarang menjadi ranah yang efektif untuk diciptakan dan direkayasa sebagai komoditas mesin budaya poluler yang disebut media televisi. Budaya massa yang memiliki alat kekuasaan dapat dicitrakan lewat "massa" yang dibentuk, dan kesenian rakyat akan dengan mudah dikonstruksi sebagai lahan komersial untuk menghasilkan keuntungan secara finansial. Persoalan kompleks THR adalah perkembangan seni populer dan bagian budaya populer yang kini berakibat pada hadirnya perubahan materi dan bentuk pertunjukan.

Industri hiburan yang terbentuk lewat perkembangan seni popular juga berdampak pada kehidupan seni pertunjukan tradisional saat sekarang dihadapkan pada persoalan yang amat rumit. Adanya tarik-menarik diantara kepentingan politik penguasa dengan kepentingan masyarakat seni tidak dapat dihindarkan. Hegemoni penguasa tidak dapat dihindari seniman sejak rezim Orde Baru berkuasa. Kebijakan yang diambil penguasa tidak terlepas dari kepentingan politis untuk mempertahankan status quo. Sehingga masalah yang timbul tidak dapat diatasi hanya dengan menjalankan manajemen yang memaksakan tugas kepemimpinan bertambah berat, disamping pemimpin harus tangguh juga memiliki inisiatif, kreatif, dan memperhatikan hubungan secara manusiawi.

Konsep mengenai budaya populer digunakan memahami sekaligus menjelaskan tentang fenomena seni popular yang berkembang sebagai objek penelitian. Budaya popular memiliki pengertian dan pemahaman berbeda, tergantung pada persoalan yang berkembang di masyarakat ataupun komunitasnya. Dalam aktivitas berkesenian dapat dilakukan secara individu, namun dalam kenyataannya sulit dilakukan maupun dijalani, sehingga kehadiran kepemimpinan sangat diperlukan untuk menunjang perkembangan maupun keberadaan seni pertunjukan. Kepemimpinan memiliki peranan besar untuk mencapai tujuan organisasi, dan seorang pemimpin dengan model kepemimpinannya harus sanggup mengadakan berbagai perubahan yang berdampak terhadap kesejahteraan organisasi, namun kharismatik sosok pemimpin hingg sekarang masih menjadi kekuatan utama bagi manajemen yang mampu mendukung dan mempertahankan kelangsungan hidup komunitas seni pertunjukan.

\section{REFERENSI}

Amirullah., \& Budiyono, H. (2004). Pengantar Manajemen. Yogyakarta: Graha Ilmu

Anirun, S. (1998). Menjadi Aktor: Pengantar Kepada Seni Peran Untuk Pentas dan Sinema. Bandung: Rekamedia Multiprakarsa bekerja sama Studiklub Teater Bandung dan Taman Budaya Jawa Barat.

Barker, C. (2011). Cultural Studies: Teori dan Praktik. terjemah Nurhadi, Bantul: Kreasi Wacana.

Bungin, B. (2012). Analisis Data Penelitian Kualitatif: Pemahaman Filosofis dan Metodologis ke Arah Penguasaan Model Aplikasi. Jakarta: Rajawali Pers.

Emzir. (2012) Analisis Data: Metodologi Penelitian Kualitatif. Jakarta: Rajawali Pers.

Fiske, J. (2011). Memahami Budaya Populer. Diterjemahkan oleh Asma Bey Mahyuddin, hal. 5, Yogyakarta: Jalasutra.

Harymawan, R. M. A. (1988). Dramaturgi. Bandung: Rosda Karya. 
Heryanto, A (ed). (2012). Budaya Populer di Indonesia: Mencairnya Identitas Pasca Orde Baru. Yogyakarta: Jalasutra.

Ibrahim, I S. (2011). Budaya Populer sebagai Komunikasi: Dinamika Popscape. dan Mediascape di Indonesia Kontemporer. Yogyakarta: Jalasutra.

Murgiyanto, S. (1985). Manajemen Pertunjukan. Jakarta : DEPDIKBUD.

Permas, Ac., Sedayono, C H., Pranoto L.H., Saputro, P. (2003). Manajemen Organisasi Seni Pertunjukan Jakarta: PPM.

Priyatmoko, Hariyono, dan Suseno, D. (2014). 2014 Tahun Kebudayaan di Jawa. Timur. Surabaya: Biro Humas dan Protokol Setdaprov.

Purba, J. (2005). Pengelolaan Lingkungan Sosial. Jakarta: Yayasan Obor Indonesia.

Purnomo, H. (2015). “Aneka Ria Srimulat: Kajian Seni Populer di Kompleks Taman Hiburan Rakyat Surabaya". Tesis Magister, Universiyas Negeri Surabaya.

Ratna, N K. (2013). Glosarium:1.250 Entri, Kajian Sastra, Seni, dan Sosial Budaya. Hal. 439 dan 442, Yogyakarta: Pustaka Pelajar.

Safaria, T. (2004). Kepemimpinan. Yogyakarta: Gaha Ilmu.

Sedyawati, E. (2008). Keindonesiaan dalam Budaya, Buku 2 Dialog Budaya: Nasional.dan Etnik, Peranan Industri Budaya dan Media Massa, Warisan Budaya dan Pelestarian Dinamis. Jakarta: Wedatama Widya Sastra.
Smiers, J. (2009). Arts Under Pressure: Memperjuangkan Keanekaragaman Budaya di Era Globalisasi. Diterjemahkan Umi Haryati. hal.168, Yogyakarta: Insist Press.

Soedarsono, R.M. (2010). Seni Pertunjukan Indonesia di Era Globalisasi. Yogyakarta: Gadjah Mada University Press.

Strinati, D. (2003). Popular Culture: Pengantar Menuju Teori Budaya Populer. Terjemahan Abdul Mukhid Yogyakarta: Bentang Budaya.

Sudikan, S Y. (1997). "Kesenian Rakyat dan Tantangan Zaman", Makalah Seminar Nasional. IKIP Semarang, 27 Agustus 1997.

Suganda, D. (2002), Manajemen Seni Pertunjukan. Bandung: STSI Press. 